\title{
ANALISIS DESAIN PENANGGULANGAN LONGSORAN PADA RUAS JALAN KUSUMA BANGSA KABUPATEN PASER PROVINSI KALIMANTAN TIMUR
}

\author{
Akhmad Gazali ${ }^{\left(1^{*}\right)}$, Fathurrahman ${ }^{(2)}$ \\ Program Studi Teknik Sipil Universitas Islam Kalimantan Muhammad Arsyad Al Banjari Banjarmasin \\ *)E-mail:akhmadgazali51@gmail.com
}

\begin{abstract}
ABSTRAK
Penelitian ini menguraikan tentang perencanaan tiang pancang yang dikombinasikan dengan kantilever sebagai desain konstruksi penanggulangan longsoran pada ruas Jalan Kusuma Bangsa Kabupaten Paser Provinsi Kalimantan Timur. Memperhatikan kondisi lereng yang telah mengalami kelongsoran dan hancurnya konstruksi penahan tanah sebelumnya yang terbuat dari kayu ulin akan membahayakan kondisi di sekitarnya. Tujuan dari penelitian ini adalah untuk mendapatkan rancangan konstruksi tiang pancang yang aman dan dapat menahan terjadinya kelongsoran. Dimana tiang pancang ini dikombinasikan dengan kantilever yang berfungsi sebagai pengaku tiang pancang tersebut dan juga sebagai penahan timbunan di belakangnya. Analisis stabilitas lereng menggunakan metode Alan W.Bishop yang diaplikasikan dalam program komputer X-Stable. Untuk perencanaan penanggulangan dengan tiang dilakukan dengan mengacu pada SNI 03-19621990 dan untuk menentukan tekanan tanah aktif digunakan metode Rankine. Hasil perhitungan dengan aplikasi X-Stable menunjukan bahwa lereng yang telah longsor dalam keadaan kritis dengan SF yang didapat sebesar 1,078, sehingga dipandang perlu adanya penanggulangan. Dari hasil analisa perancangan didapatkan desain tiang pancang yang aman yaitu tiang pancang baja dengan $\varnothing 21,63 \mathrm{~cm}$, tebal $8,2 \mathrm{~mm}$, yang dipancang sampai lapisan tanah keras sedalam $6 \mathrm{~m}$. Untuk lebar $1 \mathrm{~m}$ didapatkan jumlah tiang sebanyak 2 buah dengan jarak $75 \mathrm{~cm}$ antar as ke as tiang. Pada bagian kantilever digunakan beton bertulang dengan mutu K-225 dengan bagian telapak digunakan tulangan tarik $\varnothing 12-100$ sengkang $\varnothing 10-100$, untuk pada bagian badan digunakan tulangan tarik $\varnothing 12-100$ dengan sengkang $\varnothing 10-100$ pula. Dari hasil analisa ulang didapatkan Faktor Keamanan sebesar 3,34, dengan demikian kondisi lereng ada pada keadaan relatif aman.
\end{abstract}

Kata kunci: tiang pancang, kantilever, stabilitas lereng, kritis, penanggulangan. 
Analisis Desain Penanggulangan Longsoran..., Akhmad Gazali ${ }^{\left(1^{*}\right)}$ Fathurrahman $^{(2)}$

\section{PENDAHULUAN}

Dalam bidang Teknik Sipil, tanah merupakan dasar dari suatu konstruksi dapat dibangun.Tanah diharapkan dapat menopang beban yang bekerja di atasnya.Perencanaan yang matang sangat diperlukan, guna menghasilkan suatu konstruksi yang stabil, aman dan ekonomis.

Namun, tidak semua bangunan didirikan pada daerah yang memiliki permukaan yang datar, karena setiap daerah memiliki kondisi geografis dan geologi yang berbeda.Konstruksi yang dibangun pada daerah yang memiliki elevasi tanah yang lebih tinggi dari daerah sekitarnya, sangat rawan terhadap terjadinya kelongsoran. Tanah yang tidak datar akan menghasilkan komponen gravitasi dari berat, yang cenderung menggerakkan massa tanah dari elevasi tinggi ke elevasi yang lebih rendah. Longsoran yang terjadi akan membahayakan bangunan yang berdiri di atasnya.

Selain hal tersebut di atas, keruntuhan tanah pada lereng atau longsoran umumnya disebabkan oleh penambahan beban pada lereng, penggalian, rembesan air dan / infiltrasi air hujan. Keruntuhan dapat berlangsung dalam waktu yang relatif cepat, namun bisa juga terjadi secara berangsur-angsur.

Salah satu contoh keruntuhan lereng yang terjadi, yaitu pada ruas Jalan Kusuma Bangsa, Kabupaten Paser Provinsi Kalimantan Timur yang menjadi tinjauan dalam penelitian ini. Kondisi tanahnya berupa tanah lempung, dimana sangat dipengaruhi oleh kadar air. Kelongsoran terjadi pada musim hujan dengan intensitas air yang besar. Tanah menjadi jenuh dan bertambah berat, sehingga kuat geser tanah berkurangdan menambah gaya lateral tanah. Kondisi inilah yang menyebabkan longsornya tanah dan sangat memerlukan perhatian yang serius.

Akibat longsoran yang terjadi, menyebabkan runtuh atau rusaknya dinding penahan tanah yang sebelumnya terbuat dari pasangan kayu ulin.Untuk itu diperlukan suatu desain penanggulangan yang baik dengan memperhatikan tipe longsoran, faktor penyebab, dan kemudahan pengerjaan di lapangan.

Banyak metode yang bisa digunakan dalam mengatasi kelongsoran yang terjadi, seperti mengubah geometri lereng untuk mengurangi gaya penggerak, mengendalikan air permukaan (drainase) dan penambatan tanah (dengan bronjong, pasangan batu, tembok penahan, tiang pancang) untuk menambah gaya penahan, dan sebagainya.
Dalam penelitian ini, akan dilakukan analisis dan perencanaan desain yang cocok dengan kondisi yang terjadi, agar nantinya tidak terjadi kelongsoran serupa dikemudian hari. Sebagai tahap awal, akan dilakukan analisa stabilitas lereng pada daerah tersebut terlebih dahulu, dengan memperkirakan tipe keruntuhan yang sesuai dengan kondisi di lapangan.

Secara khusus, perumusan masalah dalam penelitian ini adalah untuk melakukan analisis desain penanggulangan keruntuhan lereng pada ruas Jalan Kusuma Bangsa, Kabupaten Paser Provinsi Kalimantan Timur. Dalam penelitian ini, permasalahan yang akan dibahas adalah perencanaan penahan longsoran yang aman dari segi teknis dan relatif mudah pengerjaannya di lapangan. Dalam perencanaan ini hanya dibatasi pada: perencanaan penanggulangan dengan menggunakan tiang dan kantilever, tidak ada beban yang bekerja pada lereng dan pada perhitungan stabilitas lereng walaupun ada karena pengaruh air, namun tidak dimasukkan karena data pengukuran muka air tidak ada. Sedangkan tujuan dari penelitian ini adalah membuat desain penanggulangan longsoran yang aman, relatif ekonomis dan sesuai dengan kondisi di lapangan.

\section{TINJAUAN PUSTAKA}

Secara umum analisis stabilitas lereng didasarkan pada konsep kesetimbangan plastis batas (limit plastic equilibrium). Adapun maksud dari analisis stabilitas pada kondisi plastis adalah untuk menentukan faktor aman dari bidang longsor yang potensial. Adapun jenis-jenis lereng ada tiga macam yang perlu diperhatikan, yaitu sebagai berikut:

1) Lereng alam, yaitu lereng yang terbentuk karena proses alam, misalnya lereng suatu bukit.

2) Lereng yang dibuat dalam tanah asli. Misalnya bilamana tanah dipotong untuk pembuatan jalan atau saluran air untuk keperluan irigasi.

3) Lereng yang dibuat dari tanah yang dipadatkan. Misalnya tanggul untuk jalan atau bendungan tanah.

Ada tiga jenis keruntuhan yang sering terjadi yaitu :

1. Keruntuhan talud dangkal/lereng (skallow slope failure)

Keruntuhan yang terjadi sepanjang bidang gelincir yang masih terletak dalam batas 
lereng atau terjadi di atas kaki lereng/muka lereng.

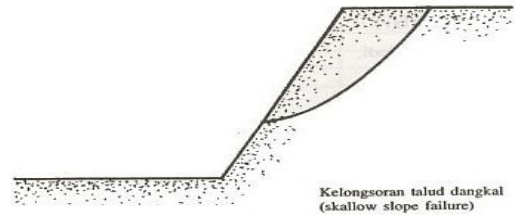

Gambar 1. Keruntuhan lereng

2. Keruntuhan ujung kaki atau melalui kaki lereng (toe failure)

Keruntuhan yang terjadi bila bidang gelincir melewati ujung bawah lereng.

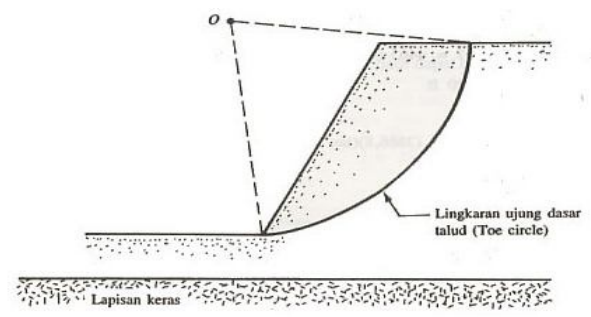

Gambar 2. Keruntuhan kaki lereng

3. Keruntuhan pada dasar lereng, di bawah kaki lereng/dasar lereng.

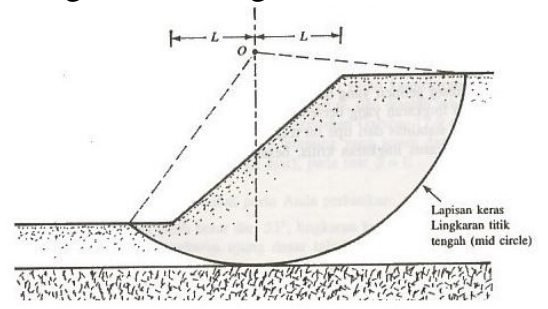

Gambar 3. Keruntuhan dasar lereng

\section{Metode Analisis Stabilitas Lereng}

Beberapa analisis menganggap bahwa bidang longsor berupa lingkaran. Hal ini dimaksudkan untuk mempermudah hitungan analisis stabilitasnya secara matematis dan dipertimbangkan mendekati bentuk sebenarnya dari bidang longsor yang sering terjadi di alam. Bila tanah tidak homogen dan aliran rembesan terjadi di dalam tanah tidak menentu, cara yang lebih cocok adalah metode irisan (Method Of Slices). Sebaliknya jika tanah homogen dan tidak ada pengaruh aliran rembesan maka analisis dapat dilakukan secara langsung atau dapat menggunakan Diagram Taylor (1984).

Untuk mendapatkan hasil yang lebih teliti, maka dalam analisis stabilitas lereng ini digunakan
Metode Alan W. Bishop (Simplified Bishop Method) (1955).Metode ini sama dengan metode Fellinius yaitu gaya-gaya yang bekerja pada sisisisi irisan resultannya nol pada arah vertikal bidang longsor, hanya saja dalam pemakaiannya agak rumit dan membutuhkan cara coba-coba (trial error) karena faktor aman nampak di kedua sisinya. Akan tetapi cara ini telah terbukti menghasilkan nilai faktor aman yang mendekati hasil hitungan dengan cara lain yang lebih teliti.
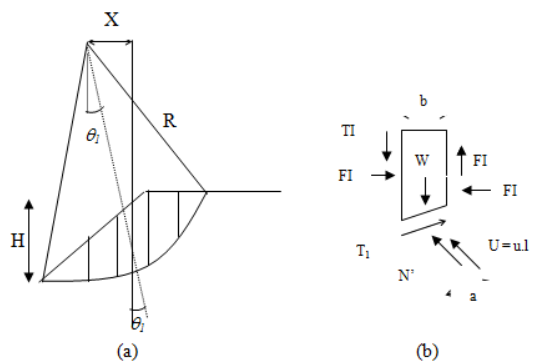

(b)

Gambar 4. (a) Analisa stabilitas lereng;

(b) Gaya yang bekerja pada irisan ke-n

\section{Keterangan:}

$W=$ Berat total (irisan) + beban (jika ada)

$N^{\prime}=$ Gaya normal effektif

$u . l$ = Gaya akibat tekanan air pori

$u=$ Tekanan air pori pada dasar irisan

$=\gamma_{w} \cdot Z_{w}$

$Z_{w}=$ Kedalaman di muka tanah

Persamaan kuat geser dalam tinjauan tegangan efektif yang dapat dikerahkan tanah, hingga tercapai kondisi keseimbangan batas dengan memperhatikan faktor aman:

$$
\tau=\frac{c^{\prime}}{F K}+(\sigma-u) \frac{\operatorname{Tan} \theta}{F K}
$$

Untuk irisan ke-i, nilai $T_{i}=\tau \cdot a_{i}$ yaitu nilai geser yang berkembang pada bidang longsor untuk keseimbangan batas. Karena itu:

$$
T_{i}=\frac{c^{\prime} \cdot a i}{F K}+\left(N-u \cdot a_{i}\right) \frac{\operatorname{Tan} \phi}{F K} \mathrm{i} .
$$

Kondisi keseimbangan momen terhadap pusat rotasi (o) antara berat massa tanah yang akan longsor dengan gaya geser total pada dasar bidang longsornya dapat dinyatakan oleh (Gambar 4):

$$
\sum W \cdot x_{i}=\sum T_{i} R
$$

Dengan $x_{i}$ adalah jarak $W_{i}$ ke pusat rotasi (o) dari persamaan (1) dan (2) dapat diperoleh: 
Analisis Desain Penanggulangan Longsoran..., Akhmad Gazali ${ }^{\left(1^{*}\right)}$ Fathurrahman $^{(2)}$

$$
F K=\frac{R \sum_{i=1}^{i=n}\left[c^{\prime} \cdot a_{i}+\left(N_{i}-u_{i} \cdot a_{i}\right) \operatorname{Tan} \phi\right.}{\sum_{i=1}^{i=n} W_{i} x_{i}}
$$

Dari kondisi kesetimbangan vertikal, jika $X_{1}-X_{i}$ dan $X_{1}-X_{i+1}$

$$
\begin{aligned}
& N_{1} \cos \theta_{i}+T_{1} \sin \theta_{i}=W_{1}+\left(X_{1}-X_{i+1}\right) \\
& N_{1}=\frac{\left[W_{1}+\left(X_{1}-X_{i+1}\right)\right]-T_{1} \sin \theta_{i}}{\cos \theta_{i}}
\end{aligned}
$$

Dengan $N_{i}^{\prime}=N_{i}-\left(u_{i} \cdot I_{i}\right)$ substitusikan persamaan (2) ke persamaan (5), maka diperoleh:

$$
N_{1}=\frac{\mathrm{W}_{1}+\left(\mathrm{X}_{1}-\mathrm{X}_{\mathrm{i}+1}\right)-\left(u_{1} \cdot a_{1} \cdot \cos \phi_{i}\right)-\left(c^{\prime} \cdot a_{1} \cdot \sin \phi_{i} \cdot a_{1} \cdot F K\right)}{\cos \phi_{i}+\frac{\left(\sin \phi_{i} \cdot \operatorname{Tan} \phi_{i}\right)}{F K}}
$$

Substitusikan persamaan (6) ke persamaan (4) maka diperoleh:

$$
F K=\frac{R \sum_{i=1}^{i=n}\left[c^{\prime} \cdot a_{1}+\operatorname{Tan} \phi_{i} \cdot \frac{\mathrm{W}_{1}+\left(\mathrm{X}_{1}-\mathrm{X}_{\mathrm{i}+1}\right)-\left(u_{1} \cdot a_{1} \cdot \cos \phi_{i}\right)-c^{\prime} \cdot a_{1} \cdot \sin \phi_{i} \cdot a_{1}}{\cos \phi_{i}+\left(\sin \phi_{i} \cdot \operatorname{Tan} \phi_{i}\right)}\right]}{\sum_{i=n}^{i=n} W_{i} \cdot x_{i}}
$$

Untuk penyederhanaan dianggap $X_{1}-X_{i+1}=0$, dengan mengambil:

$$
\begin{aligned}
& X_{1}=R \cdot \sin \phi_{i} \cdot \\
& b_{1}=a_{1} \cdot \cos \phi_{i} \cdot
\end{aligned}
$$

Substitusikan persamaan (8) dan (9) ke persamaan (7) maka diperoleh:

$$
F K=\frac{R \sum_{i-1}^{i=n}\left[\left(c^{\prime} b_{i}+\left(\mathrm{W}_{1}-u_{i} \cdot b_{i}\right) \operatorname{Tan} \phi_{i}\right) \frac{1}{\cos \phi_{i}+\sin \phi_{i} \operatorname{Tan} \phi_{i}}\right]}{\sum_{i=n}^{i=n} W_{i} x_{i}} \ldots
$$

dimana:

$$
\begin{aligned}
F K & =\text { faktor keamanan } \\
c^{\prime} & =\text { kohesi tanah efektif } \\
\phi^{\prime} & =\text { sudut gesek dalam tanah efektif } \\
b_{i} & =\text { lebar irisan ke-i } \\
W_{i} & =\text { berat irisan ke-i } \\
\phi_{i} & =\text { sudut yang didefinisikan } \\
u_{i} & =\text { tekanan air pori pada irisan ke-i }
\end{aligned}
$$

Nilai banding tekanan pori (pori preasure ratio) didefinisikan sebagai:

$$
r_{u}=\frac{u \cdot b}{W}=\frac{u}{\gamma \cdot h}
$$

dimana:

$$
r_{u}=\text { nilai banding tekanan pori }
$$

$$
\begin{aligned}
& u=\text { tekanan pori } \\
& b=\text { lebar irisan } \\
& \gamma=\text { berat volume tanah } \\
& h=\text { tinggi irisan rata-rata }
\end{aligned}
$$

Dari persamaan (10), maka bentuk lain dari persamaan faktor aman untuk analisis stabilitas lereng cara Bishop adalah:

$$
F K=\frac{\underset{i=n}{i=1}\left[\left(c^{\prime} \cdot b_{i}+\mathrm{W}_{1}\left(1-\mathrm{r}_{\mathrm{u}}\right) \operatorname{Tan} \phi^{\prime}\right) \frac{1}{\left.\cos \theta_{1}\left(1+\tan \theta_{1} \tan \phi_{i}\right)\right]}\right.}{\sum_{i=n}^{i=n} W_{i} \sin \theta_{1}} . .
$$

\section{Penanggulangan Kelongsoran dengan Menggunakan Tiang}

Tiang dapat digunakan baik untuk pencegahan maupun penanggulangan longsoran. Penggunaan tiang dimaksudkan untuk menambah momen penahan tanah. Bila tahanan tanah terhadap momen penggerak meningkat, berarti angka keamanan talud juga bertambah. Asumsi yang dipergunakan dalam konstruksi tiang, kelompok tiang menerima gaya guling dari tanah.

Untuk menghitung kebutuhan tiang permeter, terlebih dahulu ditentukan besarnya momen penggerak dari bidang longsor yang akan ditahan. Kemudian menentukan jumlah baris dan besarnya dimensi tiang, agar diketahui besarnya tegangan geser tiang dan jarak antar tiang. Dan faktor keamanan didapat dengan membandingkan antara gaya geser antara tiang dan tanah di bawah bidang longsor $\left(S_{\mathrm{ada}}\right)$ dengan gaya geser antara tiang dan tanah pada bidang longsor $\left(\mathrm{S}_{\text {desain }}\right)$.

Sesuai dengan syarat kestabilan lereng, maka dengan pemberian tiang harga angka aman sekurang-kurangnya 1,10 untuk kondisi beban sementara (kendaraan) dan sekurang- kurangnya 1,50 untuk kondisi hanya beban tetap timbunan embankment saja (talud).

\section{METODOLOGI PENELITIAN}

Metode yang digunakan dalam perancangan ini terdiri dari dua tahapan yaitu inventarisasi datadata pendukung seperti data tanah yang didapatkan dari hasil penyelidikan tanah dan data geometri berupa data sekunder dari dokumen proyek yang meliputi: layout area longsor, potongan memanjang dan potongan melintang yang menggambarkan kondisi di lapangan. Kemudian, tahapan selanjutnya dilakukan analisa stablitas 
lereng dengan aplikasi program $X$-STABLE, yang hasil/outputnya digunakan dalam proses desain tiang dan dinding kantilever.

\section{Data - Data Pendukung}

\section{a. Pengumpulan Data Tanah}

Data-data hasil penyelidikan tanah yang dibutuhkan adalah sebagai berikut:

a. Data Boring (Hand Boring)

Data tersebut dibutuhkan untuk mendapatkan informasi mengenai lapisan tanah, muka air tanah.

b. Data Sondir

Diambil untuk mengetahui nilai perlawanan konus $\left(q_{c}\right)$ dan tahanan geser pada setiap lapisan tanah dengan variasi kedalaman sampai lapisan tanah keras.

c. Data Hasil Pengujian Laboratorium.

Data ini diperlukan untuk mengethui sifat fisik (Index properties) dan sifat mekanis tanah (Engineering Propertis).

\section{b. Data Geometri}

Data geometri/profil (gambaran umum lokasi, penampang memanjang dan melintang terjadinya kelongsoran).Berfungsi untuk mengetahui deskripsi potongan kondisi lereng yang mengalami keruntuhan.

\section{Analisis Data}

\section{a. Stabilitas Lereng}

Data yang diperoleh akan dianalisa dengan menggunakan metode Alan W. Bishop secara komputerisasi melalui programXSTABLE. Dengan menginput data-data tanah seperti berat volume tanah $\left(\gamma_{\text {tanah }}\right)$, kohesi (c) dan sudut gesek dalam $(\phi)$.

Dari hasil print out $X$-Stable ini nantinya akan didapat:

1.Faktor keamanan (SF);

2.Besarnya momen penggerak;

3.Jari-jari atau radius kelongsoran lereng;

4. Titik pusat kelongsoran;

yang mana untuk selanjutnya dapat digunakan hasilnya dalam membuat perencanaan penanggulangan tersebut.

\section{Desain Penanggulangan Longsoran}

Dalam tahapan desain ini, dicoba untuk memperbesar gaya penahan dengan membuat memasang tiang sebagai penahan longsoran dan membuat dinding penahan sebagai pengaku tiang dan menahan tanah timbunan di belakangnya. Tahapan perencanaan penanggulangan kelongsoran menggunakan tiang sesuai dengan SNI 03-1962-1990.

\section{Penarikan Kesimpulan}

Kesimpulan diambil berdasarkan data dan hasil yang diperoleh dari analisis yang dilakukan.

\section{Bagan Alir Penelitian}

Jalannya penelitian dan prosedur-prosedur analisis data secara lengkap dapat dilihat dari bagan alir pada Gambar5 di bawah ini.

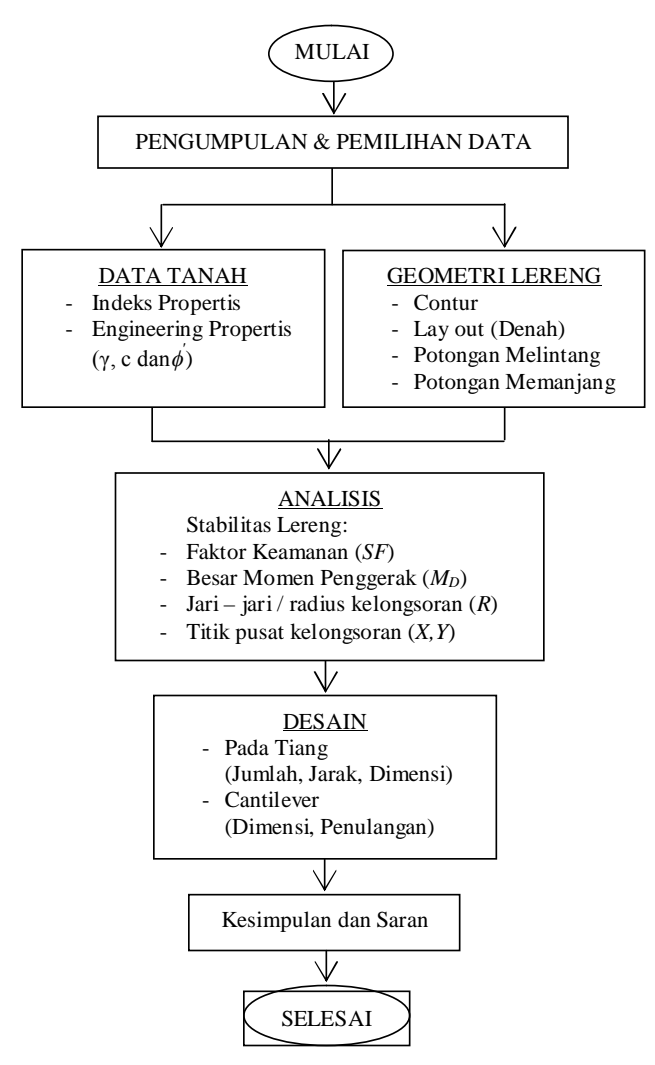

Gambar 5. Bagan Alir Penelitian

HASIL PENELITIAN

\section{Analisis Stabilitas Lereng}

Stabilitas lereng dianalisis menggunakan analisa metode Bishop yang diaplikasi program $X$ Stable ver. $3.23 \mathrm{~m}$ dengan menginput data-data tanah antara lain berat volume tanah $\left(\gamma_{t}\right)$, kohesi (c), dan sudut gesek dalam $(\phi)$, akan diperoleh hasil analisis yang dapat dilihat pada lampiran 
print out $X$-Stable. Didapatkan nilai $C_{\text {residual }}$ sebesar $0,04 \mathrm{~kg} / \mathrm{cm}^{2}$ dan nilai $\theta_{r}$ sebesar $10^{\circ}$.
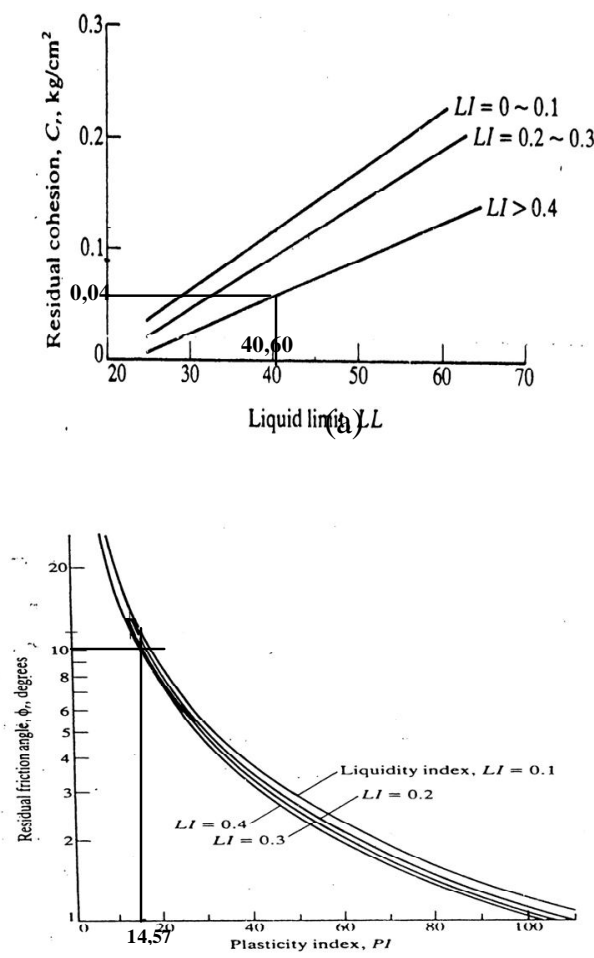

(b)

Gambar 6. (a) Grafik Hubungan antara Liquid Limit $(L L)$ dan Kohesi Residual $\left(c_{r}\right)$

(b) Grafik Hubungan antara Liquid Limit $(L L)$ dan Sudut Geser Dalam Residual

\section{Perhitungan Penanggulangan Kelongsoran dengan Hand Calculation (Manual)}

Bidang longsor dihitung secara grafis, dan dihitung dalam 1 meter lebar. Tipe kelongsoran dapat dilihat pada Gambar 7 dan hasil perhitungan gaya yang bekerja dapat dilihat pada Tabel 1 dibawah ini.

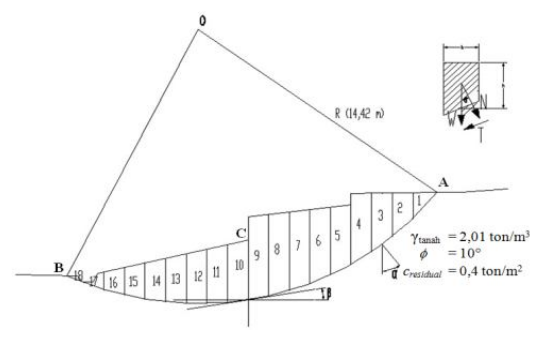

Gambar 7. Bidang Kelongsoran Lereng
Tabel 1. Perhitungan Gaya Yang Bekerja Pada Bidang Longsor

\begin{tabular}{|c|c|c|c|c|c|c|}
\hline Segmen & b & $\mathbf{h}$ & $\alpha$ & $\mathbf{W}$ & W. $\operatorname{Sin} \alpha$ & $\begin{array}{c}\text { W. Cos } \\
\alpha\end{array}$ \\
\hline 18 & 0,74 & 0,18 & $\begin{array}{c}- \\
24,00 \\
\end{array}$ & 272,42 & $-110,80$ & 248,87 \\
\hline 17 & 1,00 & 0,63 & $\begin{array}{c}- \\
21,00\end{array}$ & $1.272,33$ & $-455,96$ & $1.187,82$ \\
\hline 16 & 1,00 & 1,20 & $\begin{array}{c}- \\
16,00\end{array}$ & $2.416,02$ & $-665,95$ & $2.322,43$ \\
\hline 15 & 1,00 & 1,69 & $\begin{array}{c}- \\
12,00\end{array}$ & $3.406,15$ & $-708,18$ & $3.331,71$ \\
\hline 14 & 1,00 & 2,11 & $-8,00$ & $4.246,53$ & $-591,00$ & $4.205,20$ \\
\hline 13 & 1,00 & 2,46 & $-4,00$ & $4.943,19$ & $-344,82$ & $4.931,15$ \\
\hline 12 & 1,00 & 2,74 & 0,00 & $5.498,96$ & 0,00 & $5.498,96$ \\
\hline 11 & 1,00 & 2,94 & 4,00 & $5.915,23$ & 412,63 & $5.900,82$ \\
\hline 10 & 1,00 & 3,08 & 8,00 & $6.191,00$ & 861,62 & $6.130,75$ \\
\hline 9 & 1,00 & 4,31 & 12,00 & $8.667,92$ & $1.802,16$ & $8.478,51$ \\
\hline 8 & 1,00 & 4,20 & 16,00 & $8.436,17$ & $2.325,32$ & $8.109,37$ \\
\hline 7 & 1,00 & 4,00 & 21,00 & $8.047,44$ & $2.883,94$ & $7.512,93$ \\
\hline 6 & 1,00 & 3,73 & 24,00 & $7.490,47$ & $3.046,65$ & $6.842,88$ \\
\hline 5 & 1,00 & 3,36 & 29,00 & $6.761,84$ & $3.278,21$ & $5.914,04$ \\
\hline 4 & 1,00 & 3,41 & 33,00 & $6.863,55$ & $3.738,16$ & $5.756,25$ \\
\hline 3 & 1,00 & 2,71 & 38,00 & $5.439,26$ & $3.348,74$ & $4.286,20$ \\
\hline 2 & 1,00 & 1,85 & 44,00 & $3.720,51$ & $2.584,48$ & $2.676,31$ \\
\hline 1 & 1,00 & 1,36 & 49,00 & $2.728,58$ & $2.059,28$ & $1.790,11$ \\
\hline \multicolumn{4}{|c|}{$\Sigma$} & 92.317,558 & $23.464,482$ & $85.124,309$ \\
\hline
\end{tabular}

Dari hasil perhitungan didapatkan:

$\sum_{1}^{18} N=85.124,309 \mathrm{~kg}$

$\sum_{1}^{18} T=23.464,482 \mathrm{~kg}$

\section{Perhitungan Dimensi dan Spasi Tiang}

Menghitung banyaknya baris (n) dan jarak antar baris $(\mathrm{m})$, serta dimensi tiang yang akan dipakai:

Menggunakan Tiang Baja dengan $\tau_{\mathrm{s}}=1600$ $\mathrm{kg} / \mathrm{cm}^{2}$,

$$
\begin{aligned}
& \mathrm{M}_{\text {desain }}=\frac{M . m}{n}, \text { dicoba } \mathrm{n}=2 \text { baris } \\
& \mathrm{M}_{\text {desain }}=\frac{24314,33 \cdot m}{2} \mathrm{kgm}, \\
& \mathrm{M}_{\text {desain }}=12157,165 \mathrm{~m}
\end{aligned}
$$

Tegangan geser baja sama dengan momen penggerak $\left(\mathrm{M}_{\text {desain }}\right)$ berbanding momen lawan tiang (W). dituliskan menjadi :

$$
\begin{aligned}
& \tau_{\mathrm{s}}=\frac{M_{\text {desain }}}{W} ; \mathrm{M}_{\text {desain }}=\sigma_{\mathrm{s} . \mathrm{W}} \\
& 12157,165 \mathrm{~m}=1600 . \mathrm{W}
\end{aligned}
$$

Dari rumusan di atas, didapat hasil sebagai berikut: 
Analisis Desain Penanggulangan Longsoran..., Akhmad Gazali ${ }^{\left(1^{*}\right)}$, Fathurrahman $^{(2)}$

Tabel 2. Hasil Perhitungan Jarak Antar Baris (m)

\begin{tabular}{|c|c|c|c|c|}
\hline $\begin{array}{c}\text { Diameter } \\
(\mathbf{c m})\end{array}$ & Tebal & $\begin{array}{c}\text { Luasan } \\
(\mathbf{F})\end{array}$ & $\begin{array}{c}\text { Momen } \\
\text { Lawan }(\mathbf{W})\end{array}$ & $\mathbf{m}$ \\
\hline & $4,50 \mathrm{~mm}$ & $29,94 \mathrm{~cm}^{2}$ & $155 \mathrm{~cm}^{3}$ & $0,31 \mathrm{~m}$ \\
21,63 & $5,80 \mathrm{~mm}$ & $38,36 \mathrm{~cm}^{2}$ & $197 \mathrm{~cm}^{3}$ & $0,40 \mathrm{~m}$ \\
& $8,20 \mathrm{~mm}$ & $53,61 \mathrm{~cm}^{2}$ & $269 \mathrm{~cm}^{3}$ & $0,50 \mathrm{~m}$ \\
\hline
\end{tabular}

Digunakan Profil Tiang Baja Lingkaran dengan diameter $(\mathrm{d})=21,63 \mathrm{~cm}$, tebal $(\mathrm{t})=8,2 \mathrm{~mm}$, luasan $(\mathrm{F})=53,61 \mathrm{~cm}^{2}$ dan momen lawan $(\mathrm{W})=269 \mathrm{~cm}^{3}$. Didapatkan jarak antar as $(\mathrm{m})$ sebesar 0,5 meter. Jarak efektif tiang antara 1,5d sampai dengan 3,5d ( $\mathrm{d}=$ diameter). Apabila $\mathrm{d}=21,63 \mathrm{~cm}$, dipakai 3,5d maka jarak antar tiang sebesar 0,75 meter. Sehingga dalam perhitungan selajutnya jarak antar as sebesar 0,75 meter.

Besarnya tegangan geser dasar tiang yang terpasang $\left(\tau_{\mathrm{s}}\right)$ :

$$
\begin{aligned}
& \tau_{\mathrm{s}}= \frac{Q_{\text {desain }}}{F} ; \bar{\tau}_{S}=0,58.1600=928 \mathrm{~kg} / \mathrm{cm}^{2} \\
&= \frac{23530}{2} \times \frac{0,75}{53,61}=164,59 \mathrm{~kg} / \mathrm{cm}^{2} \\
& \tau_{\mathrm{s}}<\bar{\tau}_{S} \\
& 164,59 \mathrm{~kg} / \mathrm{cm}^{2}<928 \mathrm{~kg} / \mathrm{cm}^{2}
\end{aligned}
$$

Besarnya gaya geser antara tanah dan tiang pada talud $\left(S_{\text {ada }}\right)$ :

$$
\begin{aligned}
\mathrm{S}_{\mathrm{ada}} & =\mathrm{c}_{\mathrm{u}} \cdot \mathrm{h} \cdot \pi \cdot \mathrm{d} \\
& =1,4 \mathrm{~kg} / \mathrm{cm} 2 \cdot 310 \mathrm{~cm} \cdot 3,141592654 \cdot 21,63 \\
& =29491,45 \mathrm{~kg}
\end{aligned}
$$$$
\mathrm{cm}
$$

Besarnya gaya geser setelah dilakukan pemancangan tiang $\left(S_{\text {desain }}\right)$ :

$$
\mathrm{S}_{\text {desain }}=\frac{\mathrm{P}_{\mathrm{R}} \cdot \operatorname{Cos} \beta \cdot m}{n}=\frac{23530.0,75}{2}=8823,75 \mathrm{~kg}
$$

Faktor Keamanan:

$$
\mathrm{FK}=\frac{S_{a d a}}{S_{\text {desain }}}=\frac{29491,45}{8823,75}=3,34 \ldots . \text { AMAN }
$$

\section{Perhitungan Gaya Aksial Yang Diterima Tiang}

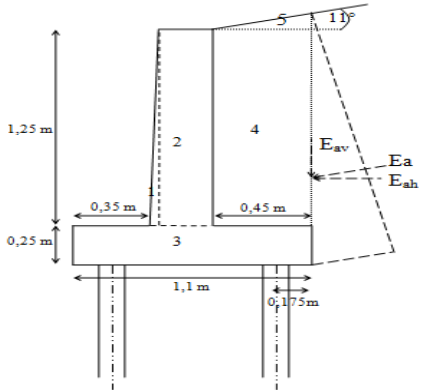

Gambar 8. Dimensi Kantilever

$$
\begin{aligned}
\gamma_{\operatorname{tanah}} & =2,01 \mathrm{ton} / \mathrm{m} \\
\beta & =11^{\circ} \\
\phi & =15^{\circ}
\end{aligned}
$$

Tinggi tanah ditambah dengan tinggi kantilever adalah:

$$
\begin{aligned}
\mathrm{H}_{\text {total }} & =0,45 \cdot \tan 11+1,25+0,25 \\
= & 0,09+1,25+0,25 \\
= & 1,59 \mathrm{~m} .
\end{aligned}
$$

Besarnya koefisien tekanan tanah aktif adalah :

$$
\begin{aligned}
& K a=\cos \beta \frac{\cos \beta-\sqrt{\cos ^{2} \beta-\cos ^{2} \phi}}{\cos \beta+\sqrt{\cos ^{2} \beta-\cos ^{2} \phi}} \\
& K a=\cos 11 \frac{\cos 11-\sqrt{\cos ^{2} 11-\cos ^{2} 15}}{\cos 11+\sqrt{\cos ^{2} 11-\cos ^{2} 15}}=0,6848
\end{aligned}
$$

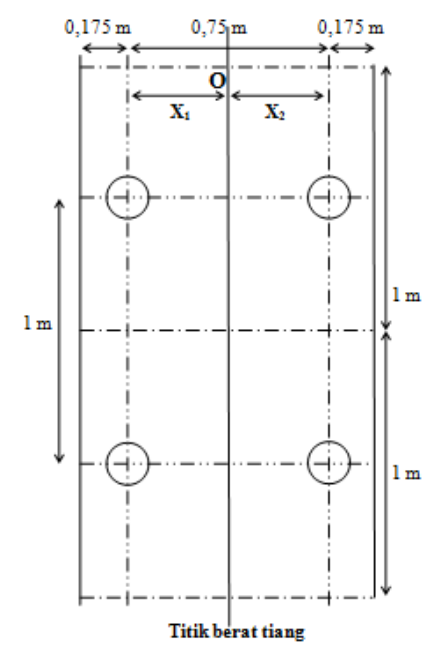

Gambar 9. Susunan Tiang Tampak Atas

Perhitungan dipandang selebar 1 meter.

- Pusat berat tiang $(O)$ dari Baris I $(X o)=0,375$ $\mathrm{m}$.

$$
V=\frac{\sum V}{n}+\frac{M \cdot x_{i}}{\sum x^{2}}
$$

Jumlah tiang $(\mathrm{n})=2$.

Absis tiang - tiang :

Baris I $\quad \mathrm{X}_{1}=-0,375 \mathrm{~m}$.

Baris II ; $\quad \mathrm{X}_{2}=0,375 \mathrm{~m}$.

$\Sigma \mathrm{x}^{2}=1.0,375^{2}+1.0,375^{2}=0,28125 \mathrm{~m}^{2}$

- Besarnya tekanan tanah aktif, yaitu :

$$
\begin{aligned}
\mathrm{E}_{\mathrm{a}} & =1 / 2 \cdot \mathrm{H}_{\mathrm{tot}}^{2} \cdot \gamma_{\mathrm{tanah}} \cdot \mathrm{K}_{\mathrm{a}} \\
& =1 / 2 \cdot 1,592 \cdot 2,01 \cdot 0,6838 \cdot 1 \\
& =1,74 \text { ton. }
\end{aligned}
$$


Analisis Desain Penanggulangan Longsoran..., Akhmad Gazali ${ }^{\left(1^{*}\right)}$ Fathurrahman $^{(2)}$

- Besarnya tekanan tanah aktif searah sumbu horizontal, yaitu :

$\mathrm{E}_{\mathrm{ah}}=\mathrm{E}_{\mathrm{a}} \cdot \operatorname{Cos} \beta=1,74 \cdot \operatorname{Cos} 11=1,708$ ton.

- Besarnya tekanan tanah aktif searah sumbu vertikal, yaitu :

$\mathrm{E}_{\mathrm{av}}=\mathrm{E}_{\mathrm{a}} \cdot \operatorname{Sin} \beta=1,74 . \operatorname{Sin} 11=0,332$ ton.

- Lengan momen terhadap titik $\mathrm{O}$ :

$\mathrm{L}=1 / 3 \times \mathrm{H}_{\text {total }}=1 / 3.1,59=0,53 \mathrm{~m}$.

- Momen terhadap titik $\mathrm{O}\left(\mathrm{M}_{\mathrm{H}}\right)$ :

$M_{H}=E_{\text {ah }} \times L=-1,708 \cdot 0,53=-0,90524$.

Tabel 3. Perhitungan Momen Akibat Gaya Vertikal

\begin{tabular}{|c|c|c|c|}
\hline Segmen & $\begin{array}{c}\text { Gaya Vertikal } \\
\text { (ton) }\end{array}$ & $\begin{array}{c}\text { Lengan } \\
\text { ke O } \\
(\mathrm{m})\end{array}$ & $\begin{array}{c}\text { Momen } \\
\text { terhadap } \\
\mathbf{O} \\
\text { (ton.m) }\end{array}$ \\
\hline 1 & $\begin{array}{c}1 / 2 . \\
0,05 \cdot 1,25 \cdot 1 \cdot 2,4 \\
=0,075\end{array}$ & $-0,167$ & $-0,012525$ \\
\hline 2 & $\begin{array}{c}0,25.1,25 \cdot 1 \cdot 2,4 \\
\quad=0,75\end{array}$ & 0,475 & 0,35625 \\
\hline 3 & $\begin{array}{c}1,1.0,25 \cdot 1 \cdot 2,4= \\
0.66\end{array}$ & 0 & 0 \\
\hline 4 & $\begin{array}{c}0,45.1,25.1 .2,01 \\
=1,131\end{array}$ & 0,325 & 0,367575 \\
\hline 5 & $\begin{array}{c}1 / 2 \\
.0,45 \cdot 0 \cdot 09 \cdot 1 \cdot 2,01 \\
=0,041\end{array}$ & 0,4 & 0,0164 \\
\hline \multirow[t]{2}{*}{ Eav } & 0,332 & 0,55 & 0,9394 \\
\hline & $\Sigma V=2,989$ & & $\begin{array}{c}\Sigma M= \\
+0.9103\end{array}$ \\
\hline
\end{tabular}

- Momen Total (terhadap titik O):

$\mathrm{M}_{\mathrm{total}}=+0.9103-0,90524=+0,00506$ ton. $\mathrm{m}$.

- Besarnya Gaya Aksial yang diterima oleh tiang: Baris I:

$$
\begin{aligned}
\mathrm{V}_{1} & =\frac{\Sigma \mathrm{V}}{\mathrm{n}}+\frac{\mathrm{M} \cdot \mathrm{Xi}}{\Sigma \mathrm{X}^{2}} \\
& =\frac{2,989}{2}+\frac{0,00506 \times(-0,375)}{0,28125} \\
& =1,4878 \text { ton }(\uparrow) . \\
\mathrm{V}_{1} & =\quad \mathrm{P}_{1}=1,4878 \text { ton. }
\end{aligned}
$$

Baris II:

$$
\begin{aligned}
\mathrm{V}_{2} & =\frac{\Sigma \mathrm{V}}{\mathrm{n}}+\frac{\mathrm{M} \cdot \mathrm{Xi}}{\Sigma \mathrm{X}^{2}} \\
& =\frac{2,989}{2}+\frac{(0,00506 \times 0,375)}{0,28125} \\
& =1,5012 \operatorname{ton}(\uparrow) . \\
\mathrm{V}_{2} & =\mathrm{P}_{2}=1,5012 \text { ton. }
\end{aligned}
$$

\section{KESIMPULAN DAN SARAN}

\section{Kesimpulan}

Berdasarkan hasil analisis desain penanggulangan longsoran pada ruas Jalan Kusuma Bangsa, Kabupaten Paser, Provinsi Kalimantan Timur dapat disimpulkan beberapa hal sebagai berikut :

1. Dari pengamatan yang dilakukan di lapangan, bahwa jenis longsoran yang terjadi adalah tipe longsoran rotasi dengan letak longsoran pada kaki lereng.

2. Penyebab dari kelongsoran sendiri adalah bertambahnya tekanan air pori, yang mengakibatkan berkurangnya kuat geser tanah. Dan besar faktor keamanan lereng pun menjadi berkurang. Hal ini dapat dilihat pada kejadian dimana longsoran tersebut terjadi pada waktu musim hujan.

3. Dari hasil analisa stabilitas lereng dengan menggunakan program $X$-STABLE didapatkan faktor keamanan lereng sebesar 1,078. Kondisi ini berarti lereng tersebut mendekati kritis, sehingga diperlukan adanya suatu konstruksi pengaman dari kelongsoran.

4. Untuk meningkatkan stabilitas dari longsoran yang terjadi, maka dibuatlah suatu konstuksi berupa kombinasi tiang pancang baja dan dinding penahan dengan perincian sebagai berikut :

a) Tiang pancang baja dengan diameter 216,3 $\mathrm{mm}$, tebal $8,2 \mathrm{~mm}$ dan panjang 6 meter. Setiap lebar $1 \mathrm{~m}$ didapatkan jumlah tiang sebanyak 2 buah dengan jarak $75 \mathrm{~cm}$ antar as ke as tiang.

b) Pada Kantilever digunakan beton bertulang dengan mutu K-225 dimana pada bagian telapak digunakan tulangan tarik $\varnothing 12-100$ dengan sengkang $\varnothing 10-100$ sedangkan pada bagian badan digunakan tulangan tarik $\varnothing 12-100$ dengan sengkang $\varnothing 10-100$.

5. Dari hasil analisa ulang, didapatkan besarnya faktor keamanan (SF) dengan penggunaan 
Analisis Desain Penanggulangan Longsoran..., Akhmad Gazali ${ }^{\left(1^{*}\right)}$, Fathurrahman $^{(2)}$

tiang tersebut sebesar 3,34 dan kondisi ini dinilai relatif aman terhadap kelongsoran.

\section{Saran}

1. Guna mencegah masuknya kembali air ke dalam tanah, maka pada bagian retakan retakan tanah yang ada sebaiknya ditutup.

2. Untuk mencegah air tidak terlalu banyak masuk ke dalam tanah, maka sebaiknya dibuat saluran drainase permukaan yang baik

3. Selain dengan membuat drainase, upaya pencegahan lainnya bisa juga berupa menanam tumbuh - tumbuhan seperti rumput dan tanaman lainnya.

\section{DAFTAR PUSTAKA}

Bowless, J. E. 199, Analisis Dan Desain Pondasi, Jilid 1 dan 2, Jakarta : Erlangga.

Craig, R.F, 1994, Mekanika Tanah, Edisi Empat, Jakarta : Airlangga.

Das, M.B. 1984, Principles Of foundation Engineriing, Second Edition, Boston PWS Kent.

Dipohusodo, I. 1994, Struktur Beton Bertulang, Jakarta: Gramedia Pustaka Utama.

Dokumen Kontrak. 2017, Proyek Penanganan Longsoran Pendopo Bupati Paser Tanah Grogot, Kalimantan Timur.

Fang, H.Y, 1991, Foundation Engineering Handbook, Second Edition

Hardiyatmo, H.C, 2003, Mekanika Tanah II, Edisi 3, Yogyakarta: Gajahmada University Press.

Hardiyatmo, H.C. 2002, Teknik Fondasi I, Edisi 2, Yogyakarta: Beta Offset.

HS, Sardjono, Pondasi Tiang Pancang, Jilid 2, Surabaya: Sinar Wijaya

Iskandar, dkk, 2005, Bahan Kuliah Struktur Beton Bertulang I, Banjarmasin: Fakultas Teknik Universitas Lambung Mangkurat.

Mochtar, I.B, Penanganan Masalah Geoteknik Terkini, Surabaya: FTSP - ITS

Naval Facilities Engineering Command, 1971, Design Manual Soil Mechanic, Foundation, and Earth Structures, Alexandria: Department of Navy

Nova, 1995, Buku Teknik Sipil, Bandung

Sharma, S. dkk, 2002, Slope Stability And Stabilization Methods, New York: John Wiley \& Sons, Inc.

Standar Nasional Indonesia 03-1962-1990, 1987, Tata Cara Perencanaan Penanggulangan Longsoran, Jakarta: Badan Standardisasi Nasional.

Wesly, L.D. 1977, Mekanika Tanah, Jakarta: Badan Penerbit Pekerjaan Umum 